Relations industrielles

Industrial Relations

\title{
Craig, Alton W.J., and Norman A. Solomon, The System of Industrial Relations in Canada
}

\section{David C. McPhillips}

Volume 49, numéro 4, 1994

Syndicats et restructuration économique

Unions and Economic Restructuring

URI : https://id.erudit.org/iderudit/050979ar

DOI : https://doi.org/10.7202/050979ar

Aller au sommaire du numéro

Éditeur(s)

Département des relations industrielles de l'Université Laval

ISSN

0034-379X (imprimé)

1703-8138 (numérique)

Découvrir la revue

Citer ce compte rendu

McPhillips, D. C. (1994). Compte rendu de [Craig, Alton W.J., and Norman A. Solomon, The System of Industrial Relations in Canada]. Relations industrielles / Industrial Relations, 49(4), 856-857. https://doi.org/10.7202/050979ar

Tous droits réservés @ C Département des relations industrielles de l'Université Laval, 1994
Ce document est protégé par la loi sur le droit d'auteur. L'utilisation des services d'Érudit (y compris la reproduction) est assujettie à sa politique d'utilisation que vous pouvez consulter en ligne.

https://apropos.erudit.org/fr/usagers/politique-dutilisation/ 


\section{RECENSIONS BOOK REVIEWS}

The System of Industrial Relations in Canada (fourth edition), Alton W.J. CRAIG and Norman A. Solomon, Scarborough, Ontario, Prentice Hall Canada, 1993, 495 p., ISBN 0-13-880519-9.

This book is designed as an introductory text in the field of industrial relations for use of both the graduate and undergraduate levels. The first four chapters set out general background material dealing with such topics as a framework for an analysis of industrial theories of labour movements and the evolution and philosophy of the labour movement in Canada. Chapters Five and Six focus on the structure of trade unions and the legislative framework under which management and unions operate. Chapters Seven through Nine deal with the actual substance of labour-management activity, namely negotiations, dispute resolution and administration of the collective agreement. Chapter Ten then focuses on problems particular to the public sector. The final two chapters of the book deal with "Outputs of the Canadian Industrial Relations System" and a "Postscript" presenting critical issues now facing the parties and those to be confronted in the future.

As is the case with all introductory texts (and particularly ones which attempt to address both the graduate and undergraduate markets), there is considerable difficulty in getting the proper balance between a conceptual academic framework and the practical application which is of most interest to the novice student. This book is now in its fourth edition and some of its earlier problems in this regard have now been addressed.

The addition of more pictures and the introduction of "windows" dealing with current events are a very welcome addition. They make the text more "user friendly" and will readily allow students to understand the practical necessity of understanding this subject matter. Additionally, they provide a basis for the instructor to easily relate the critical concepts in the field to current events which will make the teaching of the course easier. Finally, on the positive side, the book is well written and clearly organized.

I have had two basic criticisms of the book which I feel still exist to some degree. The first relates to the scope of topics covered in the text. There are so many subheadings addressed that the book is quite fragmented. Further, many areas are covered without sufficient depth while many of the more critical subjects are not thoroughly canvassed.

I think the book would be much more effective if some sub-topics were dropped and others expanded. For example, much of the material in Chapter Two dealing with areas such as the ecological system and the money market are only peripherally relevant (at least in the depth they are covered here) to the major focus of this book. Similarly, the material in Chapter Three (Theories of the Labour Movement) is broken down into 
so many pieces (e.g. Commons, Perlman, Hobbs, Hoxie, Tannenebaum, etc.) that the material is hard to follow and, in any event, means very little to an undergraduate student who has never previously been exposed to labour relations. My opinion is that it would be advantageous to remove many of these briefly discussed topics.

Many of the other areas of the book could be greatly expanded, for example, the "Postscript - some concluding observations". Among others, some of the economic material, e.g. the impact the Free Trade Agreement, should be addressed again at some length when dealing with critical issues in the future. As well, the subsection on the Charter of Rights and Freedoms is far too brief given its importance in the Canadian landscape. Indeed, some discussion of the Section 2 freedoms and Section 1 restrictions of the Charter surely belong in one of the main chapters in the text, probably in Chapter 4 , or $6 / 10$.

It is also surprising that dispute resolution through economic action (e.g. strikes / lockouts) is not more dealt with in a more prominent way in the text. Issues such as the laws relating to strikes/lockouts, picketing, non-affiliation clauses and the use of replacement workers are covered only peripherally, if at all. As well, while the book does an admirable job of dealing with some of the methods used in dispute resolution (e.g. med-arb) it does not deal in any depth with some of the very cooperative initiatives being undertaken in some management-union relationships.

Finally, there is no reference in the book to how the industrial relations system relates to the non-union regime such as employment standards and wrongful dismissal. As well, other areas which directly affect union-management relations such as human rights legislation and health and safety are not covered at all.

My second criticism is the actual structure of the book. Our Faculty has used various editions of this text for a number of years in our introductory courses at both the undergraduate and graduate levels. Our students have been consistent in their evaluations over the years that the first one hundred pages of the text causes them to lose interest in the book. Most students also agree that once the book focuses on the actual problems of labour relations, it is much better. In my view if some of the very "dry", academically "systems oriented" material which is at the beginning of the book could be placed later, the students would value the text more highly. For example, the material dealing with the competing theories of labour relations would be more comprehensible to the students after they have grasped the problems which the system is confronting.

Having said this, I reiterate that the book has improved with each edition. I hope the authors, when writing the fifth edition, will consider these comments which are meant to be constructive.

David C. MCPhiLlips

University of British Columbia 